\title{
Annelida (Oligochaeta and Aphanoneura) from the Natural Reserve of Isla Martín García (upper Río de la Plata estuary, Argentina): biodiversity and response to environmental variables
}

\author{
César, II. . $^{\mathrm{a}, \mathrm{*} *}$ \\ aDivisión Zoología Invertebrados, FCNyM, UNLP, Paseo del Bosque, s/n, 1900 La Plata, Buenos Aires, Argentina \\ ${ }^{\mathrm{b} C}$ Comisión de Investigaciones Científicas de la provincia de Buenos Aires - CIC, \\ 526 entre 10 y 11, 1900 La Plata, Buenos Aires, Argentina \\ *e-mail: icesar@fcnym.unlp.edu.ar
}

Received: October 02, 2012 - Accepted: December 27, 2012 - Distributed: February 28, 2014

(With 3 figures)

\begin{abstract}
The Island of Martín García - located in the Upper Río de la Plata, to the south of the Uruguay River - is an outcropping of the crystalline basement. Fourteen sampling sites were selected, five along the littoral section of the island and nine in inland ponds. Four major environmental variables were measured: water temperature, dissolved oxygen, electrical conductivity, and $\mathrm{pH}$. A total of 34 species of Oligochaeta and Aphanoneura were found, 30 belonging to Naididae plus one species each of the Narapidae, Lumbricidae, Enchytraeidae, and Aeolosomatidae. The thirteen most frequent species were: A. leydigi (30\%), N. bonettoi (13\%), L. hoffmeisteri (11\%), N. variabilis (10\%), S. trivandrana $(6.5 \%)$, A. pigueti (5.6\%), D. sawayai (4.5\%), D. digitata (3.5\%), C. diastrophus $(2.7 \%)$, A. costatus $(2.5 \%)$, P. longiseta (2.0\%), Enchytraeidae (1.5\%), and $A$. p. paraguayensis (1.4\%). UPGMA clustering of species based on their occurrence in different ecological conditions revealed two main species groups. Canonic-correspondence analysis (CCA) was conducted with the 15 most frequent and abundant species in the 9 sampling sites and the 4 environmental variables. Results from the CCA revealed that the order of fluctuation of the environmental variables during the sampling period was, from the greatest to the least: dissolved oxygen, conductivity, $\mathrm{pH}$, and water temperature. Approximately $97.6 \%$ of the correlations between species and environmental variables were expressed on axis 1 of the ordination diagram. Species richness correlated with the four environmental variables in the following order, from the weakest to the strongest: water temperature, $\mathrm{pH}$, electrical conductivity, and dissolved oxygen.
\end{abstract}

Keywords: biodiversity, CCA, ecology, Annelida, Martín García Island.

\section{Annelida (Oligochaeta e Aphanoneura) da Reserva Natural de Usos Múltiplos Ilha Martín García, Río de La Plata: biodiversidade e reposta às variáveis ambientais}

\begin{abstract}
Resumo
A ilha de Martín García, que está localizada na parte alta do Rio de la Plata, ao sul da desembocadura do rio Uruguai, é um afloramento do embasamento cristalino. Quatorze pontos de coleta foram selecionados, cinco ao longo da seção litoral da ilha e nove de lagoas do interior. Quatro principais variáveis ambientais foram medidas: temperatura da água, oxigênio dissolvido, condutividade elétrica e pH. Um total de 34 espécies de Oligochaeta e Aphanoneura foram encontradas, 30 pertencentes a Naididae mais uma espécie cada de Narapidae, Lumbricidae, Enchytraeidae e Aelosomatidae. As treze espécies mais frequentes foram: A. leydigi (30\%), N. bonettoi (13\%), L. hoffmeisteri (11\%), $N$. variabilis (10\%), S. trivandrana (6,5\%), A. pigueti $(5,6 \%)$, D. sawayai $(4,5 \%)$, D. digitata $(3,5 \%)$, C. diastrophus (2,7\%), A. costatus (2,5\%), P. longiseta (2,0\%), Enchytraeidae (1,5\%) e A. p. paraguayensis $(1,4 \%)$. A análise de agrupamento das espécies (UPGMA) com base na sua ocorrência em diferentes condições ecológicas revelou dois grupos de espécies principais. Análise canônica de correspondência análise (CCA) foi realizada com as 15 espécies mais frequentes e abundantes nos 9 pontos de amostragem e as quatro variáveis ambientais. Os resultados do CCA revelaram que a ordem de flutuação das variáveis ambientais durante o período de amostragem foi, desde o maior ao menor: oxigênio dissolvido, condutividade, $\mathrm{pH}$ e temperatura da água. Cerca de 97,6\% das correlações entre as espécies e as variáveis ambientais foram expressos no eixo 1 do diagrama de ordenação. A riqueza de espécies foi correlacionada com as quatro variáveis ambientais na seguinte ordem, do mais fraco ao mais forte: oxigênio a temperatura da água, $\mathrm{pH}$, condutividade elétrica, e oxigênio dissolvido.
\end{abstract}

Palavras-chave: biodiversidade, CCA, ecologia, Annelida, Ilha Martín García. 


\section{Introduction}

The annelid class Oligochaeta - considered by many authors as a bioindicator of environmental conditions is represented by a large number of genera and species present in continental waters within the benthic, pleuston, and periphyton communities (Hellawell, 1986; Rosenberg and Resh, 1993). Some genera exhibit a high degree of adaptation indicating a broad degree of plasticity with respect to environmental and evolutional challenges. A hundred species of Oligochaeta have been reported in Argentina, though most of the studies have been focused on the littoral fluvial zones and particularly on the ParanáRiver basin, where 81 especies have been found (Marchese and Paggi, 2004).

Martín García Island is a Multiple-Use Reserve located in the upper Río de la Plata estuary and was declared a natural reserve in 1969 (Tratado del Río de la Plata y su Frente Marítimo). Because of the island's status, several investigations have been conducted on the flora and fauna of the island focusing on their biodiversity and ecology. Those studies mostly dealt with hydrophilic plants (Lahitte and Hurrell, 1996), vertebrates (Juárez, 1995; Lahitte et al., 1995; Lahitte and Hurrell, 1998), and aquatic and semiaquatic Insecta (Fernández and López Ruf, 1999).
As to the fauna of the non-Insecta invertebrates, studies have also been reported on the platyhelminth Temnocephala (Damborenea et al., 1997), the aquatic annelids Oligochaeta (Armendáriz et al., 2000; Armendáriz and César, 2001), the Hirudinea (César et al, 2009), the ostracod crustaceans (César et al., 2001; César and Liberto, 2008; Liberto et al., 2012), and the aquatic and terrestrial Mollusca (Rumi et al, 1996; Rumi et al., 2004; Martín and Negrete, 2006; Rumi et al., 2007; Martín, 2008; Martín et al., 2009; César et al., 2012).

The aim of the present investigation was to report the biodiversity of annelids of the classes Oligochaeta and Aphanoneura within the natural reserve and to determine the response of the most representative species to the range of environmental variables.

\section{Material and Methods}

The island study site Isla Martín García (Figure 1) located in the upper Río de la Plata estuary (34 $11^{\circ} \mathrm{S} 58^{\circ}$ $15^{\prime} \mathrm{W}$ ) - is an outcropping of crystalline Brazilian basement from the Precambrian Era covered by Quaternary-Era sediments (from both the Pleistocene and Holocene epochs (Ravizza, 1984)). The island's coasts are asymmetric in shape, with the western receiving constant contributions

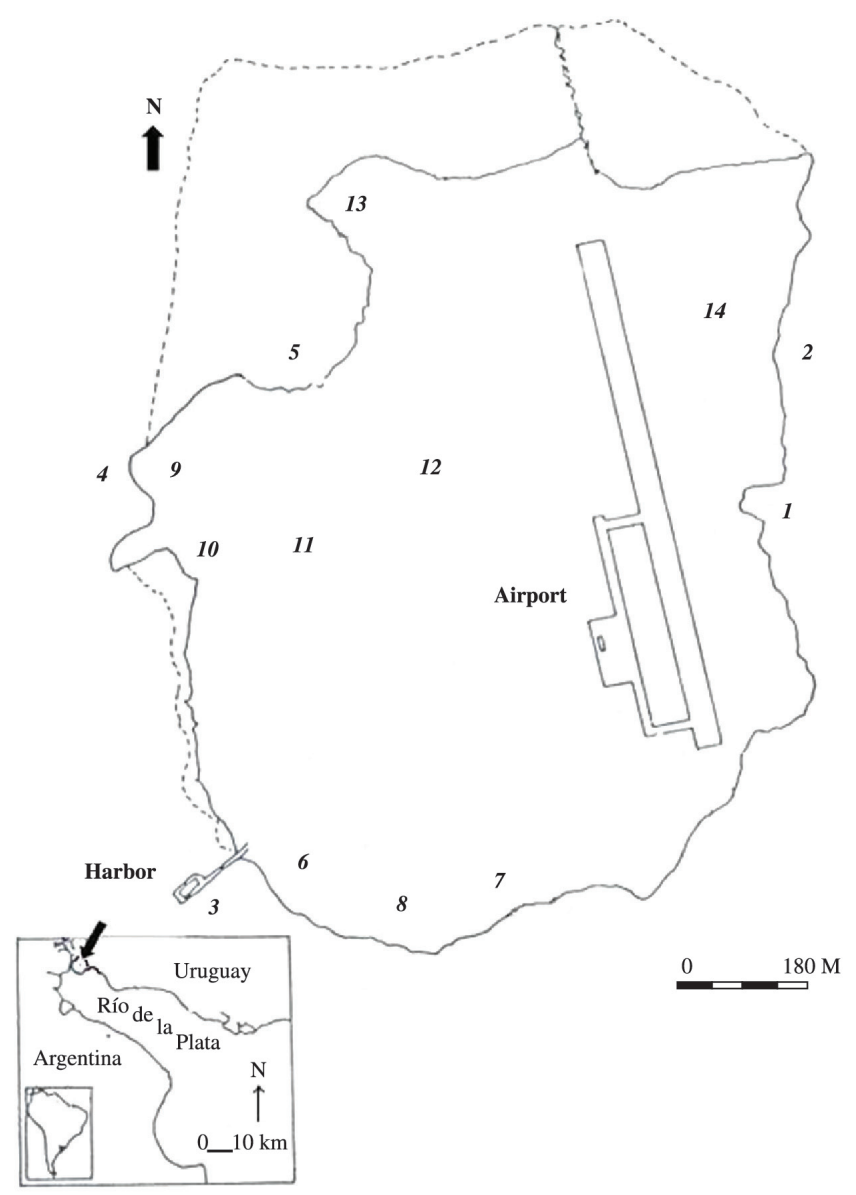

Figure 1. Sampling stations at Isla Martín García. 
of suspended silty materials from the Paraná River. That silt deposits on the rocky bottom of the river and is progressively consolidated by the coastal vegetation. The eastern and southern coasts are rocky and owing to the strong action of southeastern winds may be occasionally covered by silty-sandy sediments. This coastal asymmetry functions in producing a distinctive plant distribution. Thus, along the northern coast (Station 5, Puerto Viejo) hydrophile plants - such as Typha latifolia L., Echinodorus grandiflorus (Chan and Schutdl.) Micheli, Panicum pernambucense (Spreng.) Mez ex Pilg.; Cyperus virens Michx., Pontederia rotundifolia L. f., Ludwigia elegans (Cambess.) Hara, Alternanthera philoxenoides (Mart.) Griseb, and Ranunculus flageliformis (Sm.) - predominate. In addition, submerged aquatic vegetation - such as Potamogeton gayii A. Benn, Egeria densa Planch, and Miryiophyllum aquaticum (Vell.) Verdc. - grow within beds of the reed Schoenoplectus californicus (C. A. Mey.) Soják in the permanently flooded areas (Lahitte and Hurrell, 1996). Station 4 (Playa Basural), located near the island's garbage dump, is an area with sandy-silty sediments. In Station 3 (Puerto Nuevo), sandy-silty sediments likewise predominate along with a scarce occurrence of reedbeds. To the southeast of the island a small beach of light sand is present (Station 1), while further north lies a vast area of reedbeds (Station 2).

Inland, permanent and temporary ponds are present: some that have been formed in depressions in the former basalt quarries are located within several sectors surrounding the plateau (in the south-central portion of the island: stations $6,7,810,11,13$ ); others - formed in depressions in the marginal forest near the coasts (stations 12 and 14) or in zones close to the inland's sandy plains - are small and temporary. These ponds contain floating vegetation - such as Lemna giba L., Spirodela intermedia W. Koch., Wolfia columbiana H. Karst., Wolffiella lingulata (Hegelm.) Hegelm, Hydrocotyle sp., Azolla sp., Salvinia sp., and Ludwigia sp.

Fourteen sites were surveyed from 1995 through 1997 - 5 on the littoral zone of the island (stations 1-5) and 9 in ponds (stations 6-14) within the island (Figure 1) - during 8 seasonal collection trips. In the littoral zone of the island, samples were collected with an Ekman hand dredge $\left(175 \mathrm{~cm}^{2}\right)$, whereas in the inner ponds the sampling was done with a net (frame size, $30 \times 30 \mathrm{~cm}$; mesh size, $150 \mathrm{~mm})$. Samples were fixed in situ in $10 \%(\mathrm{v} / \mathrm{v})$ formaldehyde. In the laboratory, the collected specimens were washed on a sieve (125 microns) and the Oligochaeta separated from the vegetation, stained with erythrosin B, and preserved in $70 \%(\mathrm{v} / \mathrm{v})$ aqueous alcohol. This separation and the counting of the individuals were conducted under a stereomicroscope, but the species were identified under a conventional binocular microscope after Brinkhurst and Marchese (1992). The system and distribution proposed by Christoffersen $(2007,2011)$ was followed.

Four major environmental variables were measured at the study sites by means of portable digital sensors: water temperature $\left(\mathrm{T}^{\circ} \mathrm{C}\right)$, dissolved oxygen $\left(\mathrm{mgl}^{-1}\right)$, electrical conductivity $\left(\mathrm{mS} \mathrm{cm}^{-1}\right)$, and $\mathrm{pH}$. The relationships between the species and the environmental variables were examined through canonical-correspondence analysis (CCA), considering the fifteen most abundant and most frequently occurring species, 9 sampling stations, and 4 environmental variables (Ter Braak, 1986; Ter Braak and Verdonschot, 1995; Külköylüoğlu, 2003, 2005; Külköylüoğlu and Dügel, 2004). The mean value for each environmental variable together with species-abundance data were used in the CCA. The associations among species were evaluated by clustering analysis according to the Unweighted Pair Group Method with Arithmetic Mean (UPGMA) by means of the Jaccard Index (Crisci and López Armengol, 1983), with the species analyzed being the same as those used for the CCA. The Pearson correlation analysis was conducted and the statistical-significance values of the correlations determined by the Student $t$ test. Statistical analyses were carried out through the use of the Multi-Variate Statistical Package (MVSP), version 3.1 (Kovach, 1998).

\section{Results}

A total of 34 species of Oligochaeta and Aphanoneura were found, 30 belonging to Naididae plus one species each to the Narapidae, Lumbricidae, Enchytraeidae, and Aelosomatidae. Table 1 shows percent frequency and occurrence of each species. The thirteen most frequent members were: Amphichaeta leydigi Tauber, 1879 (30\%), Narapa bonettoi Righi \& Varela, 1983 (13\%), Limnodrilus hoffmeisteri Claparede, 1862 (11\%), Nais variabilis Piguet, 1906 (10\%), Stephensoniana trivandrana (Aiyer, 1926) (6.5\%), Aulodrilus pigueti Kowalewski, 1914 (5.6\%), Dero sawayai Marcus, 1943 (4.5\%), Dero digitata (Müller, 1773] (3.5\%), Chaetogaster diastrophus [Gruithuisen, 1828] (2.7\%), Aulophorus costatus Du Bois Reymond Marcus, 1944 (2.5\%), Pristina longiseta Ehrenberg, 1828 (2.0\%), Enchytraeidae (1.5\%), and A. p. paraguayensis [Michaelsen, 1905] (1.4\%).

The UPGMA clustering analysis (Figure 2) revealed two main species groups. The first group comprised $D$. sawayai and A. p. paraguayensis $(\mathrm{J}=0.60)$. The second consisted of several subgroups, where the group Limnodrilus udekemianus Claparede, 1862 and S. trivandrana and the one composed of the Aelosomatidae, Enchitraeidae, L. hoffmeisteri, and A. leydigi became included in the maximum-similarity index. The third group in the maximum-similarity index is composed of A. pigueti and Pristina rosea (Piguet, 1906).

The CCA (Figure 3, Table 2) revealed that the degree of fluctuation of the environmental parameters during the sampling period was, in the following order, maximum to minimum: dissolved oxygen, conductivity, $\mathrm{pH}$, and water temperature. Approximately $97.6 \%$ of the correlations between the species and these variables became expressed on axis 1 of the ordination diagram.

The correlation of species richness was weak with temperature ( $\mathrm{p}<0.05$ with $31 \%$ correlation), higher with $\mathrm{pH}(\mathrm{p}<0.01,54 \%)$, strong with electrical conductivity 
Table 1. Frequency (Freq. \%) indicates percentage of occurrence of the species as a percentage of the total number of species registered for the entire sample. The asterisk $(*)$ indicates the 15 most frequently occurring species, which group accounts for more than $90 \%$ of the total species recorded. Argentine provinces: Buenos Aires, BA; Chaco, Ch; Córdoba, Cba; Corrientes, Cor; Entre Ríos, ER; Islas Malvinas, IM; Mendoza, Mz; Misiones, Ms; Patagonia, PAT; Río Negro, RN; Salta, SAL; San Juan, SJ; Santa Fe, SF; Santiago del Estero, SE; San Luis, SL; Tucumán, Tu.

\begin{tabular}{|c|c|c|c|c|c|}
\hline Taxa & Code & Station $\mathbf{N}^{\mathbf{0}}$ & $\begin{array}{c}\text { Frequency } \\
\%\end{array}$ & $\begin{array}{c}\text { Total } \\
\text { Individuals }\end{array}$ & $\begin{array}{c}\text { Distribution in } \\
\text { Argentina }\end{array}$ \\
\hline Aeolosomatidae & $\mathrm{Ae}^{*}$ & $1,2,3,4,5$ & 0.96 & 111 & \\
\hline A.p. paraguayensis & Alp* & $6,8,9$ & 1.38 & 160 & $\mathrm{BA}, \mathrm{ER}$ \\
\hline A. leydigi & $\mathrm{Al}^{*}$ & $1,2,3,4,5$ & 30.26 & 3511 & $\mathrm{CH}$ \\
\hline A. pigueti & Ap* & $2,3,4,5$ & 5.62 & 652 & BA, CH, COR, ER, SE, SF \\
\hline A. costatus & Ac & 6,7 & 2.53 & 294 & $\mathrm{BA}$ \\
\hline A. furcatus & Af & $3,5,6,10$ & 0.05 & 6 & $\begin{array}{l}\text { BA, CH, COR, ER, SF, } \\
\text { MS, SJ }\end{array}$ \\
\hline $\begin{array}{l}\text { Aulophorus hymanae (Naidu, } \\
\text { 1962) }\end{array}$ & $\mathrm{Ah}$ & 11 & 0.03 & 4 & ER \\
\hline B. americanum & $\mathrm{Ba}$ & 9 & 0.09 & 11 & $\mathrm{BA}, \mathrm{ER}, \mathrm{MS}, \mathrm{SF}$ \\
\hline B. sowerbyi & Bs & 4,5 & 0.04 & 5 & $\mathrm{COR}, \mathrm{ER}$ \\
\hline $\begin{array}{l}\text { Chaetogaster diaphanus } \\
\text { (Gruithuisen, 1828) }\end{array}$ & Cdp & $3,5,6$ & 0.66 & 77 & $\mathrm{BA}, \mathrm{ER}, \mathrm{MZ}$ \\
\hline C. diastrophus & $\mathrm{Cdt}^{*}$ & $1,2,34$ & 2.71 & 314 & ER \\
\hline Dero botrytis Marcus, 1943 & $\mathrm{Db}$ & $6,9,10,11$ & 0.76 & 88 & $\mathrm{BA}, \mathrm{COR}, \mathrm{ER}$ \\
\hline D. digitata & Dd & 6 & 3.45 & 400 & BA, ER, MS \\
\hline Dero obtusa d'Udekem, 1885 & Do & 5 & 0.06 & 7 & $\mathrm{BA}, \mathrm{COR}, \mathrm{CBA}, \mathrm{ER}$ \\
\hline D. sawayai & Ds* & $\begin{array}{c}1,2,3,4,5 \\
6,7,8,9\end{array}$ & 4.45 & 516 & ER \\
\hline Enchytraeidae & $\mathrm{En}^{*}$ & $1,2,3,4,5$ & 1.47 & 171 & \\
\hline E. tetraedra & Et & $1,3,4,5$ & 0.2 & 23 & CBA, ER, RN, SF, SL, \\
\hline L. hoffmeisteri & $\mathrm{Lh}^{*}$ & $1,2,3,4,5$ & 10.77 & 1249 & $\begin{array}{l}\text { BA, CBA, CH, ER, SAL, } \\
\text { SJ, RN, MS, SF }\end{array}$ \\
\hline L. udekemianus & $\mathrm{Lu}^{*}$ & $3,4,5$ & 0.58 & 67 & $\begin{array}{l}\text { BA, CBA, ER, PAT, SF, } \\
\text { SJ, TU }\end{array}$ \\
\hline N. variabilis & $\mathrm{Nv}^{*}$ & $2,3,4,5,6$ & 10.14 & 1177 & ER, IM, MS, SF \\
\hline N. bonettoi & $\mathrm{Nb}^{*}$ & $1,2,3$ & 12.5 & 1450 & $\mathrm{BA}, \mathrm{ER}$ \\
\hline P. a. aequiseta & Prae* & $2,5,7$ & 0.83 & 96 & BA, ER, SF, SJ \\
\hline Pristina breviseta Bourne, 1891 & Prb & 4,5 & 0.03 & 4 & $\mathrm{BA}, \mathrm{CH}, \mathrm{ER}, \mathrm{SJ}$ \\
\hline P. longiseta & $\mathrm{Pl}^{*}$ & $1,4,6$ & 2.01 & 233 & $\begin{array}{l}\text { BA, CBA, CH, COR, MS, } \\
\text { SE, SF, SJ, TU }\end{array}$ \\
\hline P. proboscidea & Prp & 8 & 0.03 & 3 & $\mathrm{BA}, \mathrm{ER}, \mathrm{MS}, \mathrm{SF}$ \\
\hline $\begin{array}{l}\text { Pristina synclites Stephenson, } \\
1925\end{array}$ & Prs & 3,4 & 0.05 & 6 & $\mathrm{BA}, \mathrm{COR}, \mathrm{CH}$ \\
\hline Pristina acuminata Liang, 1958 & Pra & 4,5 & 0.86 & 100 & $\mathrm{SF}$ \\
\hline P. rosea & Prr* & $\begin{array}{l}2,3,4,5 \\
\quad 8,9\end{array}$ & 0.51 & 59 & $\mathrm{BA}, \mathrm{CH}, \mathrm{ER}, \mathrm{SJ}$ \\
\hline P. notopoda & Prn & 6 & 0.03 & 3 & $\mathrm{BA}, \mathrm{ER}, \mathrm{MS}$ \\
\hline P. osborni & Pro & $1,2,4$ & 0.24 & 28 & $\begin{array}{l}\text { BA, CBA, COR, ER, } \\
\text { MZ, PAT, TU }\end{array}$ \\
\hline S. evelinae & $\mathrm{Se}$ & 4,5 & 0.13 & 15 & $\mathrm{BA}, \mathrm{CH}, \mathrm{COR}, \mathrm{ER}$ \\
\hline Slavina sawayai (Marcus, 1944) & Ss & 9 & 0.01 & 1 & $\mathrm{BA}, \mathrm{ER}$ \\
\hline S. trivandrana & $\mathrm{St}^{*}$ & $3,4,5$ & 6.52 & 757 & BA, ER \\
\hline $\begin{array}{l}\text { Stylaria lacustris (Linnaeus, } \\
\text { 1767) }\end{array}$ & $\mathrm{S} 1$ & 4,5 & 0.03 & 4 & $\mathrm{BA}$ \\
\hline $34 \mathrm{sp}$ & & & & 11602 & \\
\hline
\end{tabular}




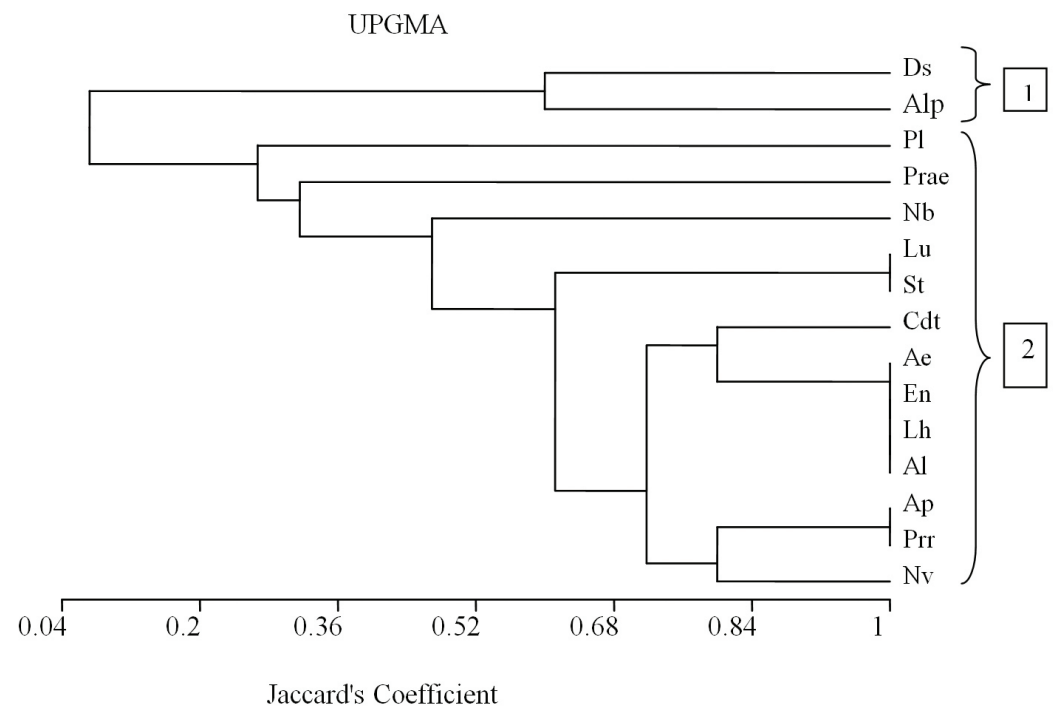

Figure 2. UPGMA dendrogram provided from binary (presence/absence) data. Based on their occurrence two main groups are clustered. First group included (Ds and Alp). Second group included (Pl, Prae, Nb, Lu, St, Cdt, Ae, En, Lh, Al, Ap, Prr and $\mathrm{Nv}$ ).

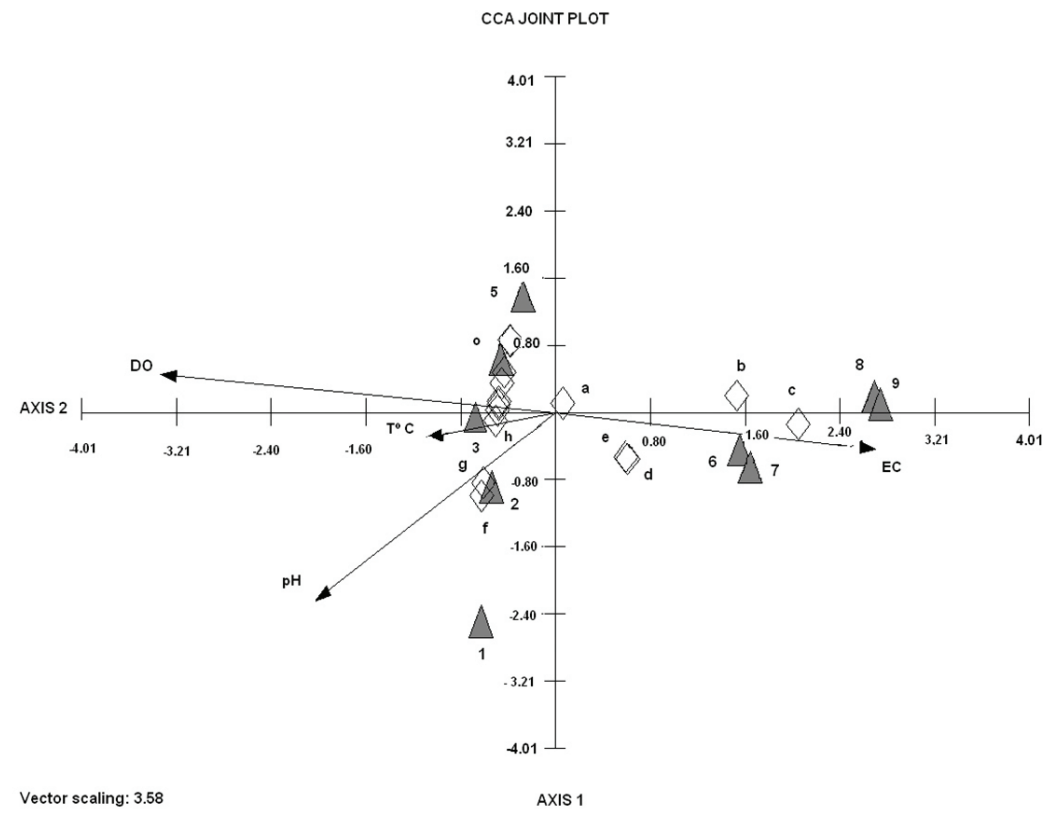

Figure 3. Canonical correspondence analysis diagram of sampling stations, fifteen species and four environmental variables. Species abbreviations: a, Nv; b, Ds; c, Alp; d, Prae; e, Pl; f, Nb: g, Cdt; h, En; i, Lh, J, Ap; k, Ae; 1, St; m, Al; n, Prr; o, Lu. Abreviation Sites: 1-9.

Table 2. Main Results from the Canonical correspondence analysis (CCA).

\begin{tabular}{lrrr}
\hline & Axis 1 & Axis 2 & Axis 3 \\
\hline Eigenvalues & 0.670 & 0.283 & 0.159 \\
Percentage & 42.138 & 17.770 & 9.985 \\
Cum. Percentage & 42.138 & 59.909 & 69.894 \\
Cum. Constr. Percentage & 58.806 & 83.605 & 97.540 \\
Spec .env. Correlations & 0.964 & 0.891 & 0.847 \\
\hline
\end{tabular}

( $\mathrm{p}<0.01,61 \%$ ), and highest with dissolved oxygen (p $<0.01,91 \%$ ) (Table 3$)$.

$N$. variabilis was located in the portion nearest to the center of the ordination diagram, thus indicating a great plasticity with respect to environmental variables. This species was accordingly found along the coast and in the inland ponds (e.g., Station 6). Pristina a. aequiseta Bourne, 1891, P. longiseta, D. sawayai, and A. p. paraguayensis 


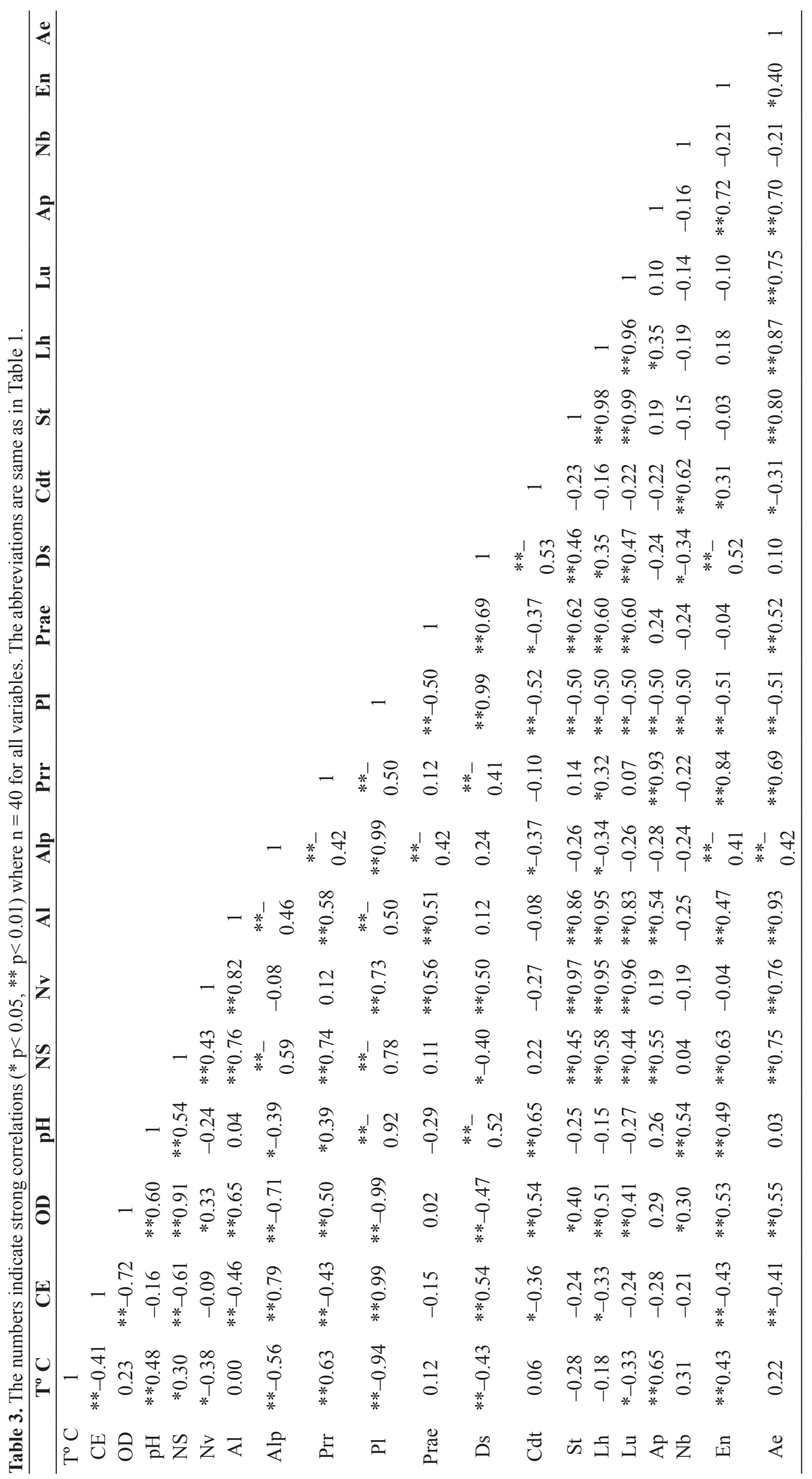


exhibited medium adaptability and the closest relationship to conductivity. The prevalence of Narapa bonettoi and C. diastrophus correlated mainly with the $\mathrm{pH}(\mathrm{p}<0.01$, at a $54 \%$ and $65 \%$ correspondence, respectively); while the occurrence and abundance of the taxa Enchytraeidae and Aeolosomatidae, together with A. leydigi, A. pigueti, L. hoffmeisteri, P. rosea, S. trivandrana, and L. udekemianus - all being found along the coast - were mainly associated with levels of dissolved oxygen and temperatures near the mean values.

\section{Discussion}

Inland and littoral aquatic environments in the reserve Isla Martín García are rich in Oligochaeta and Aphanoneura (34 species).

Most of the studies on Oligochaeta from the littoral fluvial region in Argentina have been focused on the ParanáRiver basin. Those studies provided information on the benthos, along with the fauna associated with macrophites, but the most frequently reported species belonged to the pleustonic community (Marchese and Paggi, 2004). Of the 25 species of Naidinae registered on the Isla Martín García, 9 (Table 1) were recorded only in the benthos, 7 in both the benthos and the pleuston, and 7 exclusively in the pleuston. With respect to the Tubificinae, Bothrioneurum americanum Beddard, 1894 was present in the pleustonic community, while the remaining 4 species were located in the benthic communities of the island's littoral.

The family Naididae was the richest in species, with the other families contributing only a single species each. The species with the highest relative abundances were A. leydigi, $N$. bonettoi, L. hoffmeisteri, N. variabilis, S. trivandrana, A. pigueti, D. sawayai, D. digitata, C. diastropuhus, A. costatus, $P$. longiseta, and A. p. paraguayensis. This assemblage of species is similar to that previously recorded by Behrend et al. (2009) - in the upper Paraná River along the Brazilian section of that flood plain - comprised by D. digitata, Aulophorus furcatus (Müller, 1774), D. sawayai, P. aequiseta, P. leidyi, Pristina proboscidea Beddard, 1896, Pristina notopoda Cernosvitov, 1937, Slavina evelinae (Marcus, 1944), S. trivandrana, A. pigueti, L. hoffmeisteri, and B. americanum for the Naididae along with $N$. bonettoi for the Narapidae. Many of these latter species have not been cited either for the Argentine section of the upper Paraná River (Varela et al., 1983) or for the middle Paraná River and its tributaries (Marchese, 1986, 1987; Marchese and Ezcurra de Drago, 1992; Pavé and Marchese, 2005; Galizzi and Marchese, 2007).

Most of the species reported from Martín García Island had a general distribution throughout Argentina that also corresponded to that of the provinces included in the Paraná, Uruguay, and Río de la Plata river systems (Table 1). A. pigueti, A. costatus, A. furcatus, Eiseniella tetraedra Savigny, 1867, L. hoffmeisteri, L. udekemianus, P. longiseta and Pristina osborni (Walton, 1906) were among the most widely distributed species in Argentina. As to other distributions, A. costatus, B. americanum,
$N$. bonettoi, and D. sawayai are known to be neotropical species, while $A$. pigueti, Branchiura sowerbyi Beddard, 1892, L. hoffmeisteri, L. udekemianus, and N. variabilis are considered to be cosmopolitan.

The results from the clustering analysis revealed the presence of two main groups of species. The first consisting in D. sawayai, A. p. paraguayensis $(\mathrm{J}=0.60)$, and D. sawayai - had been recorded in the inland ponds and littoral environments of Martín García Island and also included $A$. lairdi as a shared species in the ponds (stations 6, 8, and 9). The second group contained several subgroups, one of which included the littoral species L. udekemianus and S. trivandrana that shared the maximum similarity index ( $\mathrm{J}=1$; stations $3-5)$ along with a second subgroup composed of littoral taxa, the Aelosomatidae and Enchitraeidae plus L. hoffmeisteri and A. leydigi ( $\mathrm{J}=1)$. Finally, a third subgroup participating in the maximum similarity index comprised $A$. pigueti and $P$. rosea in addition to $N$. variabilis $(\mathrm{J}=0.8)$, with the latter species being also found inland. Similar associations among the species had been reported by Pavé and Marchese (2005) from urban rivers that flow into the middle Paraná River.

The results of the species responses to the environmental variables indicated that $N$. variabilis was the only species at the center of the ordination diagram, thus confirming the cosmopolitan nature of that species - namely, its ability to thrive in different habitats, including saline waters and mosses, and to tolerate high levels of organic pollution (Collado de La Peña, 1994). This species showed the greatest abundance at stations 4 and 5, with those sites - and especially number 5 - being associated with silty substrates and the presence of vegetation. $N$. variabilis was also registered at Station 6 (average conductivity $=1343.5 \mathrm{mS} \mathrm{cm}^{-1}$ ). $P$. $a$. aequiseta, P. longiseta, D. sawayai, and A. p. paraguayensis, however, were the species most associated with medium values of conductivity. Pavé and Marchese (2005) had recorded medium to high values of conductivity (631-1501 $\mathrm{mS} \mathrm{cm}-1$ ) for those species in the urban rivers that flow into the middle Paraná River. The optimum $\mathrm{pH}$ values for $N$. bonettoi and $C$. diastrophus were similar to the optima for those same species previously reported in different sections of the Paraná River (Marchese, 1994; Pavé and Marchese, 2005; Behrend et al., 2009).

In his studies on the zoobenthos of the Arrecifes River (Buenos Aires province) and its main tributaries, Sampóns (1988) mentioned certain species of Oligochaeta - such as $N$. variabilis, P. aequiseta, L. hoffmeisteri, and A. piguetithat were also found on Martín García Island and considered here in the CCA. As to the response of these species to the environmental variables cited for the island, and in consideration of the values previously reported by Sampóns (1988), the populations of $N$. variabilis - and likewise of $P$. aequiseta - on Martín García Island developed under similar values of temperature and $\mathrm{pH}$, and at medium to high levels of conductivity.

In contrast, the most frequent species on the island's littoral - e. g., A. leydigi, A. pigueti, L. hoffmeisteri, P. rosea, $S$. trivandrana, and L. udekemianus - were associated mainly 
with levels of dissolved oxygen and temperature near the mean values and, accordingly, are generally recognized as being cosmopolitan species of worldwide distribution.

Acknowledgements - Financial support for this work was provided by an institutional grant from the Comisión de Investigaciones Científicas de la Provincia de Buenos Aires (CIC) the Facultad de Ciencias Naturales y Museo, Universidad Nacional de La Plata (Proyect $\mathrm{N}^{\circ}$ 636) and (Proyect PICT N ${ }^{\circ}:$ 2008-2042). The author wish to thank Dr. Donald Haggerty, a career investigator and native English speaker, who edited the final version of the manuscript.

\section{References}

ARMENDÁRIZ, LC. and CÉSAR, II., 2001. The distribution and ecology of litoral Oligochaeta and Aphanoneura (Annelida) of the Natural and Historical Reserve of Isla Martín García, Río de la Plata river, Argentina. Hydrobiolgia, vol. 463, p. 207-216. http://dx.doi.org/10.1023/A:1013120128722

ARMENDÁRIZ, LC., CÉSAR, II. and DAMBORENEA, MC., 2000. Oligoquetos en ambientes lénticos en la Reserva Natural e Histórica de la Isla Martín García, Río de la Plata Superior, Argentina. Asociación Ciencias Naturales del Litoral, vol. 31, no. 1-2, p. 73-79.

BEHREND, RDL., FERNANDES, SEP., FUJITA, DS. and TAKEDA, AM., 2009. Eight years of monitoring aquatic Oligochaeta from the Bahía and Ivinhema Rivers. Brazilian Journal of Biology, vol. 69, supplement 2, p. 559-571. PMid:19738963. http://dx.doi. org/10.1590/S1519-69842009000300011

BRINKHURST, RO. and MARCHESE, M., 1992. Guía para la identificación de oligoquetos acuáticos continentales de Sud y Centroamérica. Asociación de Ciencias Naturales del Litoral. Santo Tomé (S. F.) Argentina. 207 p. (Colección Climax nº 6. Segunda Edición).

CÉSAR, II., ARMENDÁRIZ, LC. and DAMBORENEA, C., 2001. Ostrácodos (Crustacea) de la Isla Martín García, Río de la Plata, Argentina. Natura Neotropicalis, vol. 32, no. 2, p. 147-151.

CÉSAR, II. and LIBERTO, R., 2008. Ostracoda ¿Posibles Indicadores de Deterioro Ambiental de la Reserva de Usos Múltiples Isla Martín García? Ciencia, vol. 3, no. 5, p. 99-108.

CÉSAR, II., MARTÏN, SM., GULLO, BS. and LIBERTO, R., 2009. Biodiversity and ecology of Hirudinea (Annelida) from the Natural Reserve of Isla Martín García, Río de la Plata, Argentina. Brazilian Journal of Biology, vol. 69, no. 4, p. 1107-1113. PMid:19967181. http://dx.doi.org/10.1590/S1519-69842009000500014

CÉSAR, II., MARTÍN, SM., RUMI, A. and TASSARA, MA., 2012. Mollusks (Gastropoda and Bivalvia) of the Multiple-Use Reserve Martín García Island, Río de la Plata River: biodiversity and ecology. Brazilian Journal of Biology, vol. 72, no. 1, p. 1-10. PMid:22437379.

CRISCI, JV. and LÓPEZ ARMENGOL, MF., 1983. Introducción a la teoría y práctica de la taxonomía numérica. Washington: Ed. OEA. p. 132. (Serie de Biología, no. 26).

CHRISTOFFERSEN, M.L., 2007. A catalogue of aquatic microdrile oligochaetes (Annelida: Clitellata) from South America. Acta Hydrobiologica Sinica, vol. 31, supplement, p. 59-86.

-, 2011. Catalogue of the Lumbricidae (Annelida, Clitellata, Lumbricoidea) from South America, with remarks on the systematics of the Lumbricina. Zoosystema, vol. 33, no. 2, p. 141-173. http:// dx.doi.org/10.5252/z2011n2a2

COLLADO DE LA PEÑA, R., 1994. Oligoquetos acuáticos del cuadrante noroccidental de la Península Ibérica: taxonomía, biología y ecología. Universidade da Coruña. 223 p. Tesis de Doctorado. Available from: <http://hdl.handle.net/2183/5618>.

DAMBORENEA, MC., CÉSAR, II. and ARMENDÁRIZ, LC., 1997. Especies de Temnocephala (Platyhelminthes: Temnocephalidae) de la Isla Martín García, Buenos Aires, Argentina. Neotropica, vol. 43, no. 109-110, p. 123-124.

FERNÁNDEZ, LA. and LÓPEZ RUF, M., 1999. Coleoptera y Heteroptera acuáticos y semiacuáticos de la Isla Martín García (Provincia de Buenos Aires). Physis Secc B, vol. 57, no. 132133 , p. $1-4$

GALIZZI, MC. and MARCHESE, M., 2007. Descomposición de hojas de Tessaria integrifolia (Asteraceae) y colonización por invertebrados en un cauce secundario del Río Paraná Medio. Interciencia, vol. 32 , no. 8, p. 535-540.

HELLAWELL, JM., 1986. Biological Indicators of freshwater pollution and environmental management. London: Elsevier Applied Science. $546 \mathrm{p}$

JUÁREZ, MC., 1995. Estatus de residencia y categorización trófica de las aves en la Reserva Natural Isla Martín García, Río de la Plata Superior. Neotropica, vol. 41, no. 105-106, p. 83-88.

KOVACH, W., 1998. Multi-Variate Statistical Package. ver. 3.01. Pentraeth.

KÜLKÖYLÜOĞLU, O., 2003. Ecology of freshwater Ostracoda (Crustacea) from Lakes and Reservoirs in Bolu, Turkey. Journal Freshwater Ecology, vol. 18, no. 3, p. 343-347. http://dx.doi.org $/ 10.1080 / 02705060.2003 .9663968$

,- 2005 . Ecology and phenology of freshwater ostracods in Lake Gölköy (Bolu, Turkey). Aquatic Ecology, vol. 39, no. 3, p. 295304. http://dx.doi.org/10.1007/s10452-005-0782-5

KÜLKÖYLÜOĞLU, O. and DÜGEL, M., 2004. Ecology and spatiotemporal patterns of Ostracoda (Crustacea) from Lake Gölcük (Bolu, Turkey). Archiv für Hydrobiolgie, vol. 160, no. 1, p. 67-83. http://dx.doi.org/10.1127/0003-9136/2004/0160-0067

LAHITTE, HB., HURRELL, JA., CANDA, G. and TRUCCO ALEMÁN, C., 1995. Poblaciones de Tupinambis teguixin (SauriaTeidae) de la Isla Martín García (Buenos Aires, Argentina). I Etnobiología y Encuadre Metodológico-Cognitivo. Pinaco, vol. 2, p. 45-62.

LAHITTE, HB. and HURRELL, JA., 1996. Plantas Hidrófilas de la Isla Martín García (Buenos Aires, República Argentina). Ed. La Plata, CIC. p. 236. (Serie informe, no. 52).

-, 1998. Catálogo de las Aves de la Isla Martín García (Buenos Aires, Argentina). Ed. La Plata, CIC. p. 53-69. (Serie informe, no. 53).

LIBERTO, R., MESQUITA-JOANES, F. and CÉSAR, II., 2012. Dynamics of pleustonic ostracod populations in small ponds on the Island of Martín García (Río de la Plata, Argentina). Hidrobiología, vol. 688, p. 47-61. http://dx.doi.org/10.1007/s10750-011-0600-0

MARCHESE, M. 1986. Nuevos aportes al conocimiento de los Oligoquetos del río Paraná Medio y algunos tributarios. Studies on Neotropical Fauna and Environment, vol. 21, p. 231-249. http://dx.doi.org/10.1080/01650528609360709

-, 1987. The ecology of some benthic Oligochaeta from the Paraná River. Hydrobiologia, vol. 155, p. 155-209. 
-, 1994. Population dynamics of Narapa bonettoi Righi and Varela, 1983 (Oligochaeta: Narapidae) from the main channel of the Middle Paraná River, Argentina. Hydrobiologia, vol. 278, p. 103-108.

MARCHESE, M. and EZCURRA DE DRAGO, I., 1992. Benthos of the lotic environments in the middle Paraná River system: transverse zonation. Hydrobiologia, vol. 237, p. 1-13. http:// dx.doi.org/10.1007/BF00008422

MARCHESE, M. and PAGGI. AC., 2004. Diversidad de Oligochaeta (Annelida) y Chironomidae (Diptera) del Litoral Fluvial Argentino. In ACEÑOLAZA, FC. (Ed.). Temas de la Biodiversidad del Litoral fluvial argentino. Tucumán: INSUGEO. Miscelánea 2, p. 217-224.

MARTÍN, SM., 2008. Individual growth Heleobia piscium in natural populations (Gastropoda: Cochliopidae) from the Multiple Use Natural Reserve Isla Martín García, Buenos Aires, Argentina. Revista Brasileira de Biologia = Brazilian Journal of Biology, vol. 68 , no. 4, p. 617-621. PMid:18833484.

MARTÍN, SM., CËSAR, II. and LIBERTO, R., 2009. Distribution of Deroceras reticulatum (Müller, 1774) (Pulmonata Stylommatophora) in Argentina with first record of the Reserva de Usos Múltiples Isla Martin Garcia, Río de la Plata superior. Brazilian Journal of Biology, vol. 69 no. 4, p. 1115-1119. PMid:19967182. http:// dx.doi.org/10.1590/S1519-69842009000500015

MARTÍN, SM. and NEGRETE, LHL., 2006. Primer registro de Heleobia guaranitica (Doering, 1884) (Gastropoda: Cochliopidae) en la Reserva Natural de Usos Múltiples Isla Martín García. Comunicaciones Sociedad Malacología Uruguay, vol. 9, no. 89 , p. $71-73$

PAVÉ, PJ. and MARCHESE, M., 2005. Invertebrados bentónicos como indicadores de calidad del agua en ríos urbanos (ParanáEntre Ríos, Argentina). Ecología Austral, vol. 15, p. 183-197.

RAVIZZA, GB., 1984. Principales aspectos geológicos del cuaternario en la isla Martín García, Río de la Plata Superior.
Revista de la Asociación Geológica Argentina, vol. 39, no. 1-2, p. $125-130$

ROSENBERG, DM. and RESH, VH., 1993. Freshwater Biomonitoring and Benthic Macroinvertebrates. New York: Chapman \& Hall. 504 p.

RUMI, A., GUTIÉRREZ GREGORIC, DE., ROCHE, MA. and TASSARA, MP., 2004. Population structure in Drepanotrema kermatoides and D. cimex (Gastropoda, Planorbidae) in natural conditions. Malacologia, vol. 45, no. 2, p. 453-458.

RUMI, A., GUTIÉRREZ GREGORIC, DE. and ROCHE, A., 2007. Growth rates fitting using the von Bertalanffy model: analysis in natural populations of Drepanotrema spp. (Gastropoda: Planorbidae). Revista Biología Tropical, vol. 55, no. 2, p. 559567. PMid:19069766.

RUMI, A., MARTIN, SM., TASSARA, MP. and DARRIGRAN, GA.,1996. Moluscos de agua dulce de la Reserva Natural e Histórica Isla Martín García. Río de la Plata, Argentina. Comunicaciones Sociedad Malacológica de Uruguay, vol. 8, no. 70-71, p. 7-12.

SAMPÓNS, MR., 1988. Zoobentos del río Arrecifes (Buenos Aires, Argentina) y sus principales tributaries. Iheringia. Série Zoologia, vol. 68, p. 63-82.

TER BRAAK, CJF., 1986. Cannonical Correspondance Analysis: A new eigenvector technique for multivariate direct gradient analysis. Ecology, vol. 67, p. 1167-1179. http://dx.doi.org/10.2307/1938672

TER BRAAK, CJF. and VERDONSCHOT, PFM., 1995. Cannonical correspondence analysis and related multivariate methods in aquatic ecology. Aquatic Sciences, vol. 57, no. 3, p. 255-289. http://dx.doi.org/10.1007/BF00877430

VARELA, ME., BECHARA, JA. and ANDREANI, NL., 1983. Introducción al studio del bentos del Alto Paraná. Ecosur, vol. 10, no. $19-20$, p. $103-126$ 